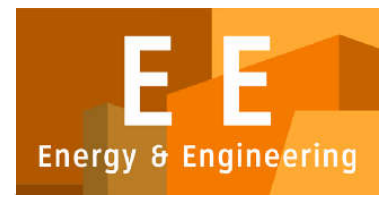

PAPER - OPEN ACCESS

\title{
Analisa Rantai Pasokan Hijau Studi Kasus: Perusahaan Pengelasan Besi (Baja)
}

$\begin{array}{ll}\text { Author } & : \text { Gina Lathifah, dkk } \\ \text { DOI } & : 10.32734 / \text { ee.v2i4.652 } \\ \text { Electronic ISSN } & : 2654-704 \mathrm{X} \\ \text { Print ISSN } & : 2654-704 \mathrm{X}\end{array}$

Volume 2 Issue 4 - 2019 TALENTA Conference Series: Energy \& Engineering (EE)

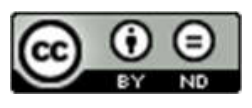

This work is licensed under a Creative Commons Attribution-NoDerivatives 4.0 International License.

Published under licence by TALENTA Publisher, Universitas Sumatera Utara

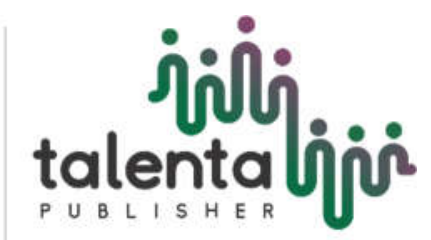




\title{
jiditi talentalioni TALENTA Conference Series
}

Available online at https://talentaconfseries.usu.ac.id

\section{Analisa Rantai Pasokan Hijau Studi Kasus: Perusahaan Pengelasan Besi (Baja)}

\author{
(Analysis Green Supply Chain Case Study: Iron Welding Company (Steel) )
}

\author{
Gina Lathifah, Bezaleel Gabriel, Yolanda Putri Syarifah, Khairul Fahmi, Andreas Tedd, \\ Mulya Sultoniq Lubis
}

Universitas Sumatera Utara, Fakultas Teknik Industri, Medan, Indonesia

ginalathifah0998@naver.com, yolandaputry2802@gmail.com, bezaleelgabriel0@gmail.com

\begin{abstract}
Abstrak
Industri adalah kegiatan ekonomi yang mengolah bahan baku dan/atau memanfaatkan sumber daya industri sehingga menghasilkan barang yang mempunyai nilai tambah atau manfaat lebih tinggi, perusahaan merupakan salah satu usaha yang berbasis Usaha Kecil Menengah (UKM ) dan bergerak dalam bidang pembuatan produk logam besi. Perusahaan melakukan usaha bisnis yang menyediakan produk berupa pagar pintu besi, canopi, teralis, dan railing dari besi. Dalam menjalankan usahanya, Perusahaan sudah menerapkan prinsip Green Supply Chain dengan supplier, menjadi pemasok sumber bahan utama dalam pengolahan produksi logam di UKM. Green Supply Chain Manajemen adalah managemen rantai pasok yang berhubungan dengan aspek lingkungan untuk memaksimalkan keuntungan dan efektivitas kerja dengan memperhatikan lingkungan. Tujuan penelitian adalah mengidentifikasi adanya konsep ramah lingkungan dalam rantai pasok perusahaan. Dalam proses produksi, dihasilkan bermacam jenis olahan logam dengan limbah atau waste yang banyak seperti percahan besi, potongan besi dan scrap dimana waste tersebut masih dapat di olah kembali. Perusahaan menerapkan konsep Green Supply Chain, yang dapat dibuktikan dari cara perusahaan melakukan proses pengolahan limbah besi dengan mencairkan menjadi plat besi yang berkualitas lebih rendah. Kualitas besi yang dihasilkan oleh distributor dari waste mempunyai persentasi kadar besi sebesar 35\% yang dilakukan. Kemudian hasil plat besi yang didapat didistribusikan kembali kepada konsumen maupun distributor lain.
\end{abstract}

Kata kunci: Logam; Green Supply Chain Management; Supplier

\begin{abstract}
Industry is an economic activity that processes raw materials and / or utilizes industrial resources so as to produce goods that have added value or higher benefits, the company is one of the businesses based on Small and Medium Enterprises (SMEs) and is engaged in manufacturing metal metal products. The company runs a business that provides products in the form of metal door fences, canopies, trellis, and railing from iron. In running its business, the Company has applied the principle of Green Supply Chain with suppliers, becoming a supplier of the main material source in processing metal production in SMEs. Green Supply Chain Management is supply chain management that deals with environmental aspects to maximize profits and work effectiveness with regard to the environment. The research objective is to identify the existence of environmentally friendly concepts in the company's supply chain. In the production process, various types of metal products are produced with a lot of waste or waste such as iron scrap, scrap iron and scrap where the waste can still be processed again. The company applies the Green Supply Chain concept, which can be proven from the way the company carries out the processing of iron waste by melting it into a lower quality iron plate. The quality of iron produced by distributors from waste has a percentage of iron content of $35 \%$. Then the results of the obtained iron plate is distributed back to consumers and other distributors.
\end{abstract}

Keywords: Metal; Green Supply Chain Management; Supplier.

(C) 2019 The Authors. Published by TALENTA Publisher Universitas Sumatera Utara

Selection and peer-review under responsibility of Seminar Nasional Institut Supply Chain dan Logistik Indonesia

(ISLI) 2019

p-ISSN: 2654-7031, e-ISSN: 2654-704X, DOI: 10.32734/ee.v2i4.652 


\section{Introduction}

Pertumbuhan ekonomi yang pesat dan ekspansi industri besar-besaran membuat manusia cenderung menguras dan menggunakan sumber daya alam lebih tinggi dari sebelumnya[1]. Pada saat yang bersamaan pembangunan dan polusi yang dihasilkannya menyebabkan kerusakan yang sangat besar pada lingkungan hidup yang kemudian dapat merusak ekologi. Perusahaan Harus bertanggung jawab terhadap limbah yang dihasilkan sehingga dapat mengurangi pencemaran lingkungan. Perusahaan yang peduli terhadap lingkungannya akan berdampak pada kesadaran yang tinggi dari konsumen sehingga mengakibatkan tingkat persaingan di pasar tidak lagi berorientasi pada mutu, harga dan ketepatan waktu lebih kepada pengiriman tetapi isu lingkungan. Hal ini tentunya perlu mendapatkan perhatian serius dari perusahaan untuk mengelola suatu rantai pasok. [2] Konsep Green Chain Supply merupakan manajemen rantai pasokan yang berhubungan dengan aspek lingkungan. Manajemen rantai pasokan yang berbasis "green" penting untuk diterapkan karena selama ini ukuran kinerja rantai pasokan biasanya tidak memperhatikan dampak terhadap lingkungan. Contohnya limbah pengelasan yang merupakan buangan atau sisa-sisa yang dihasilkan oleh UKM berupa sisa-sisa pengelasan ataupun pemotongan. [3]Limbah tersebut biasanya hanya dibiarkan atau dibuang begitu saja di penampungan limbah dan tidak diolah kembali sehingga menyebabkan pencemaran lingkungan, tentu saja hal ini dapat merugikan warga atau masyarakat sekitar. [4]Green Supply Chain merupakan loop tertutup yang didalamnya terdapat aktivitas untuk melakukan reuse,remanufacturing,atau recycling dari material menjadi material baru atau produk lainnya yang memiliki nilai dipasar. [5] Melakukan analisis rantai pasok melalui analisis kualitatif menggambarkan rantai pasok dan rantai nilai sedangkan analisis kuantitatif untuk mengetahui nilai tambah dan pembentukan rantai nilai..

\section{Metode Penelitian}

Penelitian ini bersifat eksploratif dengan teknik survey sebagai alat pengumpul data. Variabel yang dituju pada penelitian ini adalah Green Supply Chain Management. Pengumpulan data dilakukan dengan:

1. Observasi atau studi lapangan yang digunakan untuk mempelajari permasalahan yang ada ditempat kerja.

2. Wawancara dengan menentukan atribut-atribut yang akan digunakan serta dengan memberikan pertanyaan kepada narasumber terkait.

3. Penyebaran Kuesioner yang digunakan untuk mendapatkan data-data yang diperlukan dan selanjutnya akan diolah.

4. Melakukan studi literatur dengan mencari dan menentukan metode yang akan digunakan sebagai pengolahan data. Bidang usaha yang dikerjakan pada UKM ini meliputi pembuatan pintu pagar, pagar pintu besi, canopi, teralis, dan railing dari besi. Langkah langkah pembuatan dilakukan dengan tahapan:

1. Mengukur benda kerja yang akan dibuat sesuai pesanan dari konsumen.

2. Memotong benda kerja yang telah di ukur.

3. Merapikan hasil potongan dengan menggunakan gerinda.

4. Membuat rangka luar untuk acuan.

5. Menyambung benda kerja dengan menggunakan las.

6. Membersihkan kerak hasil pengelasan pada benda kerja.

7. Merapikan kembali hasil pengelasan dengan menggunakan gerinda.

8. Melakukan proses dempul pada benda kerja yang terlihat cacat untuk selanjutnya di amplas.

9. Pengecatan benda kerja sesuai keinginan konsumen dan selanjutnya proses penjemuran.

\section{Hasil dan Pembahasan}

Rantai pasok pada UKM ialah sebagai berikut:

1. Pemasok Besi (Supplier): Merupakan tempat untuk mendapatkan besi yang kemudian akan diolah.

2. Agen (Distributor) : Merupakan tempat untuk menyalurkan lempengan besi kepada pengrajin besi untuk diolah serta memberikan jenis dan ukuran besi sesuai keinginan yang sudah jadi dan siap untuk dijual.

3. Pengrajin : Merupakan tempat untuk menyalurkan besi kepada pengrajin besi ( LAS) untuk diolah serta memberikan varian produk pada besi yang akan dibuat seperti pagar, traili, dan canopi besi hasil pengelasan yang sudah jadi akan siap untuk dijual. 
4. Konsumen : Merupakan tempat untuk menjual hasil pengolahan besi menjadi barang jadi yang siap digunakan sesuai kebutuhan kemudian dari hasil pemakaian, konsumen dapat memesan kembali barang tersebut.

5. Pengecer : merupakan tempat untuk menjual limbah limbah hasil dari pengelasan dan akan diolah kembali menjadi produk yang ber- Value dengan tingkat rendah 35\% dari sebelumnya.

6. Konsumen 2 : Merupakan tempat untuk menjual hasil pengolahan besi recovery atau hasil daur ulang menjadi barang jadi yang siap digunakan sesuai kebutuhan atau dapat dijual kembali.

Aliran 1 : Merupakan aliran barang antar pemasok besi dan agen dimana agen membeli bahan baku dari pemasok Aliran 2 : Merupakan tempat untuk menumpuk besi kemudian diserahkan kembali ke pengrajin besi untuk diolah Aliran 3 : Merupakan aliran barang antara pengrajin dengan agen, dimana pengrajin membeli bahan bakunya untuk diolah dari agen.

Aliran 4 : Merupakan aliran barang antara pengrajin dengan konsumen, dimana pengrajin menjual produk jadi kepada konsumen untuk dinikmati.

Aliran 5 : Aliran barang pengrajin memberikan limbah nya kepada pengecer untuk dapat di daur ulang.

Aliran 6 : Merupakan aliran barang antara pengecer dengan konsumen, dimana pengecer memberikan produk hasil daur ulang nya untuk digunakan atau dijual kembali.

Dilihat bahwa aliran rantai pasok menerapkan prinsip green supply chain dimana limbah hasil olahan di distribusikan kembali dan menjadi nilai tambah sehingga dapat meningkatkan produktivitas dan nilai jual pasar terhadap produk besi.

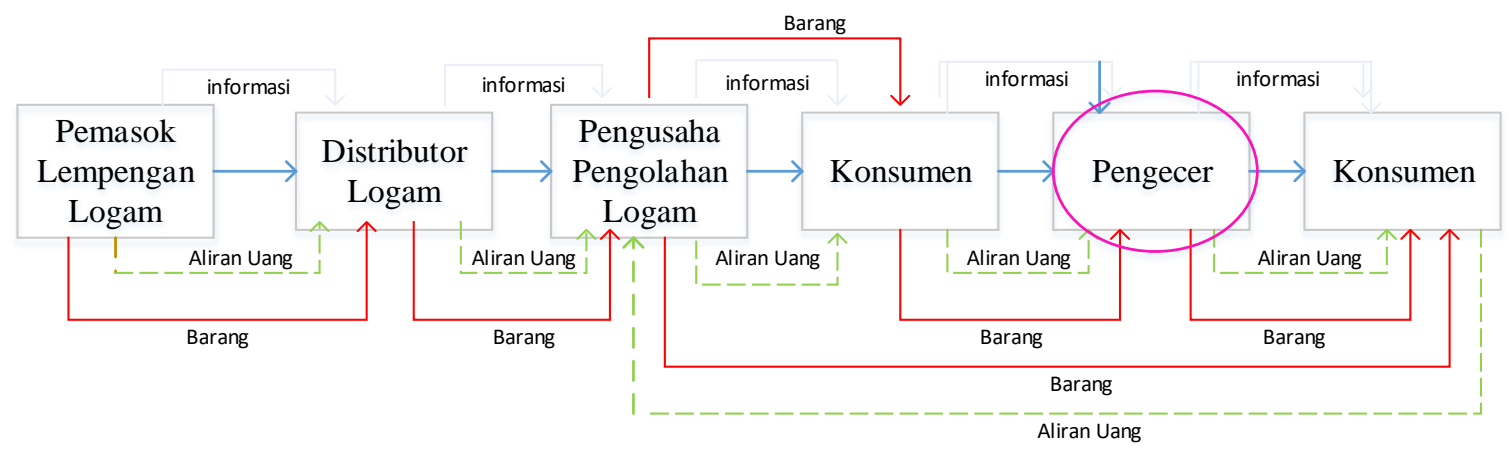

Gambar 1. Gambar Aliran Supply Chain

\section{Kesimpulan}

Berdasarkan dari tujuan penelitian, hasil pengolahan data, pembahasan, analisa terdapat beberapa kesimpulan yang dapat diambil, antara lain: UKM CV. XYZ memiliki 6 elemen jaringan supply chain management ada pemasok besi dimana pemasok besi menjadi supplier utama besi,lalu ada agen ( distributor) dimana agen membeli besi dari pemasok lalu menyerahkan besi pada pengrajinnya untuk dijadikan produk pagar besi, canopi besi dan lain lain, lalu ada konsumen dimana tempat agen menjual produknya, sisa olahan produk besi kemudian didistribusikan kembali ke pengecer, untuk dapat didaur ulang menjadi produk baru yang bernilai tambah dan dapat dijual dipasar, kemudian dari pengecer di jual kembali ke tangan konsumen ataupun penjual lain yang ingin membeli hasil olahan limbah tersebut. output yang dihasilkan dari penjualan yang dilakukan oleh CV. XYZ ini berupa barang jadi yang dapat langsung di distribusikan kepada konsumen.

\section{Referensi}

[1] Delen, D., Kuzey, C. \& Uyar, A.. 2013. Measuring Firm Performance Using Finansial Aatios : A Decision Tree Approach. Expert Systems With Applications.

[2] Griffin, Ricky.2004.Managemen,edisi VII.Jakarta : Erlangga.

[3] Pujawan, I Nyoman. (2005). Supply Chain Management. Guna Widya. Surabaya.

[4] Susanty.aries.2017.Penilaian Implementasi Green Supply Chain Management.Semarang

[5] H. Juliza, H. Sawarni, (2019) "Value Chain Analisys and Value Added Enchancement Indonesia Crude Palm Oil Supply Chain". Medan 